\title{
Proline-Rich Protein PRCC
}

National Cancer Institute

\section{Source}

National Cancer Institute. Proline-Rich Protein PRCC. NCI Thesaurus. Code C70996.

Proline-rich protein PRCC (491 aa, $252 \mathrm{kDa}$ ) is encoded by the human PRCC gene. This protein may be involved in mitotic checkpoint regulation. 